\title{
RUANG BERMAIN KOTA KAWASAN EPICENTRUM
}

\author{
Kevinn Sukhayanto ${ }^{1)}$, Tony Winata ${ }^{2)}$ \\ 1) Program Studi S1 Arsitektur, Fakultas Teknik, Universitas Tarumanagara, kevin_sukhayanto@hotmail.com \\ 2) Program Studi S1 Arsitektur, Fakultas Teknik, Universitas Tarumanagara, tonywinata@ft.untar.ac.id \\ Masuk: 10-01-2020, revisi: 27-01-2020, diterima untuk diterbitkan: 09-05-2020 (doi: 10.24912/stupa.v2i1.6791)
}

\begin{abstract}
Abstrak
Jakarta sebagai kota metropolitan dengan intensitas kegiatan tinggi, seringkali memberikan tekanan pada masyarakatnya. Kegiatan berintensitas tinggi dan berulang ini yang akhirnya memunculkan permasalahan-permasalahan mental seperti stress dan depresi, juga permasalahan mental kegiatan repetitif ini juga menyebabkan permasalahan sosial, yang mengisolasi setiap individu pada masyarakat kota pada ruang rutinitasnya masing-masing. Permainan menjadi sarana pemecah rutinitas, memecah ruang yang mengisolasi individu dari komunitas, memberikan perasaan menyengankan, sebagai sarana penyegaran individu dari rutinitas mereka, bermain menjadi solusi terbaik untuk memberikan rasa senang serta mengembalikan hubungan antara individu dengan komunitasnya. Masyarakat kota membutuhkan sebuah platform yang dapat memberi "jeda" dari rutinitas mereka. Sebuah platform yang menyediakan ruang bagi masyarakat kota untuk berisitrahat, bermain, dan bersosialisasi bersama dalam rangka penyegaran diri. Sebagai platform penyegaran yang ideal bagi masyarakat kota diusulkan sebuah ruang bermain kota yang berlokasi di kawasan Epicentrum, kawasan Epicentrum ini memiliki ruang-ruang penting berlangsungnya rutinitas kota seperti kantor, universitas, serta perumahan vertikal. Ruang Bermain ini memiliki macam kegiatan dari yang sifatnya aktif (olahraga) hingga pasif (terapi), proses perancangan melalui pertimbangan berbagai pola dan alur kegiatan yang mungkin terjadi di dalamnya sehingga menghasilkan ruang-ruang kegiatan yang multiguna serta dapat digunakan semua orang dari berbagai macam rentang usia dan latar belakang. Dengan perencanaan dan perancangan Ruang Bermain Kota di Kawasan Epicentrum diharapkan dapat menjadi sebuah simpul kegiatan baru bagi kawasan yang inklusif, serta memberikan warna baru pada kehidupan kawasan Epicentrum.
\end{abstract}

Kata kunci: inklusif; multiguna; platform; permainan; ruang bermain

\begin{abstract}
Play as a way for breaking the routine, rupturing the space that isolated individuals from the community, to give a feeling of fun, to rejuvenate individuals from their routines, Therefore Play is the best way to give the feeling of fun and joy also to restore the relationship between individuals with their community. City community needed an activities knot that fastens every activity within the city, in the city context this knot referred to as a platform, in the form of an object architecture. In-Play, architecture objects have a role to maintain the perspective of every individual, various ways to interact as well as a distinctive interpretation of architectural elements, so that makes architecture is not a limit or a barrier between program. Creating architecture space that is inclusive to all those. With great planning and design hopefully in the future Urban Playscape at Epicentrum will bring more vibrant life to the district and introduce a real meaning of 'play' to the people with a simple yet sustainable design.
\end{abstract}

Kata kunci: inclusive; versatile ; platform; play; playground

\section{PENDAHULUAN}

Jakarta sebagai kota metropolitan dengan intensitas kegiatan yang tinggi, memberikan tekanan pada masyarakatnya. Intensitas kegiatan yang tinggi dan berulang ini menghasilkan 
permasalahan mental dan sosial pada masyarakat kota seperti stress, depresi serta mengisolasi setiap individu pada masyarakat kota pada ruang rutinitasnya masing-masing. Permasalahan ini mendorong munculnya kebutuhan akan sebuah ruang "jeda" baru bagi kehidupan masyarakat kota Jakarta. Sebuah ruang yang dapat menjadi ruang beristirahat, bermain dan bersosialisasi, ruang yang digunakan sebagai ruang untuk penyegaran kembali fisik dan mental masyarakat kota.

Kawasan Epicentrum merupakan sebuah kawasan superblock di Kuningan, yang merupakan salah satu area perkantoran-perumahan terpopuler di Kuningan. Kawasan yang sangat berkembang dengan banyaknya gedung perkantoran, perumahan vertikal, serta pengembangan prasarana yang sangat lengkap, namun sangat disayangkan kawasan Epicentrum ini tidak hidup. Masyarakat kawasan Epicentrum datang ke kawasan hanya untuk bekerja atau pulang ke rumah, hampir tidak ada aktivitas di ruang-ruang terbuka kawasan. Ruang-ruang terbuka ini menjadi sebuah ruang mati yang disiapkan pengembang hanya untuk "pertunjukan", hal ini dikarenakan ruang terbuka yang disediakan oleh pengelola kawasan terlalu sepi program, atau terlalu eksklusif. Seringkali dalam pengelolaan sebuah kawasan di kota pengembang menjadikan keuntungan sebagai satu-satunya tujuan pengembangan sehingga melupakan aspek-aspek kehidupan masyarakatnya. Seperti pembentukan banyak kawasan komersil tanpa memperhatikan keseimbangannya terhadap ruang terbuka publik non-komersil. Hal ini yang akhirnya menyebabkan masyarakat segan untuk berkegiatan di ruang publik dan memilih untuk berkegiatan di ruang rutinitasnya masing-masing. Diperlukan sebuah platform inklusif dan kaya program yang dapat memberikan penyegaran bagi masyarakat kawasan, sebuah ruang kaya program tempat masyarakat kawasan berisitrahat, bermain dan bersosialisasi.

Proyek yang diusulkan berupa ruang bermain bagi masyarakat kawasan, yang memiliki macam kegiatan dari yang sifatnya aktif (olahraga) hingga pasif (terapi), proses perancangan melalui pertimbangan berbagai pola dan alur kegiatan yang mungkin terjadi di dalamnya sehingga menghasilkan ruang-ruang kegiatan yang multiguna serta dapat digunakan semua orang dari berbagai macam rentang usia dan latar belakang. Dengan perencanaan dan perancangan Ruang Bermain Kota di Kawasan Epicentrum diharapkan dapat menjadi sebuah simpul kegiatan baru yang inklusif bagi kawasan, serta memberikan warna baru pada kehidupan kawasan Epicentrum.

\section{KAJIAN LITERATUR}

\section{Third Place}

Menurut Ray Oldenberg pada bukunya yang berjudul "The Great Good Place" Third place di definisikan sebagai sebuah ruang publik tempat diantara first place (home) dan second place (workplace). Oldenberg mendefinisikan third place sebagai sebuah ruang publik dimana orangorang dapat berkumpul dan berinteraksi serta menjadi tempat untuk melupakan masalah dan menikmati kebersamaan dan percakapan diantara pelaku.

Third place menjadi neutral ground dimana semua orang yang datang menjadi setara, tidak ada hirarki. Semua pengunjung datang sebagai orang yang berkebutuhan untuk berinteraksi dengan orang-orang lain yang tidak dikenali, sehingga segala "atribut" yang dikenakan pada first place dan second place menjadi tidak berlaku. Third Place juga dideskripsikan sebagai tempat yang "unpretentious" kesederhanaan ini yang menjadikan third place sebagai tempat yang mampu dijangkau semua orang, (orang tidak segan untuk datang).

Sebagai tempat tujuan orang orang untuk berinteraksi, conversation menjadi main activity dari Third Place. Sebagai bagian dari komunitas penting bagi Third Place untuk memiliki orangorang yang rutin berkunjung / regulars, serta memiliki kemudahan aksesibilitas untuk "membuka diri" bagi para regulars. 
Sebagai tempat untuk memecah rutinitas penting bagi Third Place untuk memiliki mood dominan yang "Playful". Sehingga Third Place juga menjadi area leisure, Third Place tidak hanya menjadi sebuah tempat interaksi namun memberi kegembiraan bagi pengunjungnya.

\section{Third Place through Humanistic Perspective}

Seiring berlalunya waktu, rutinitas kita semakin tertanam kedalam hidup kita. Seperti berganti ke mode Autopilot, kita melewati hari tanpa perlu berpikir. Semakin kita mengambil bagian dalam rutinitas ini, rutinitas akan semakin menjadi bagian dari identitas kita, dan semakin sulit kita untuk keluar dari rutinitas tersebut. Ketika terjadi perubahan besar dalam hidup kita, kita cenderung takut dan defensif. Kita percaya-daripada kita merasakan bahwa rutinitas ini sangat penting bagi diri kita. Sehingga untuk keluar dari rutinitas yang telah dipegang lama akan menjadi pikiran yang sulit.

Rutinitas menjadi distraction negatif dalam hidup, ketika kita membiarkan distraction ini kemudian akan mendorong kematian emosi, spiritual, dan fisik, yang berarti kita terlalu takut untuk meninggalkan harmful yet convinient relationship, dan stuck didalam kebuntuan pekerjaan. Hal ini menyebabkan kita tidak akan menemukan kebahagiaan nyata serta tujuan hidup. Ketika kita disadarkan dari distraction yang mengganggu mimpi kita, kita jadi hilang arah dan tujuan dan bertanya "am I missing something? Is this what I really want to do?". Apakah third place menjadi sebuah distraction dalam sebuah rutinitas, atau rutinitas adalah sebuah distraction dalam sebuah "life". Ketika kita membiarkan rutinitas menjadi reality maya, rutinitas ini yang sebenarnya menjadi sebuah distraksi dalam kehidupan.

Melalui bukunya Space and Place, Yi Fu Tuan mengasumsikan pemahaman mengenai space sebagai kategori dari persepsi (Tuan mendiskusikan hubungan antara space dan time dalam permasalahan tersebut, tetapi bukan merupakan inti dari permasalahan, mengingatkan pengarang bahwa bagaimana secara linguistik pernyataan tersebut tidak berlawanan tapi saling terkait (kusut;tangled), dan memberikan sebuah konsep bahwa persepsi pada sebuah ruang merupakan satu kesatuan tubuh yang saling melengkapi secara fungsional dan maka dari itu saling terikat oleh suatu kesatuan biologis yang disebut sebagai human beings. Melalui pendekatan ini, ia mematahkan penjelasan bagaimana ruang (space) dibentuk melalui geometris geometris yang tersusun secara abstrak. Tuan menyatakan perbedaan dari geometrical space, yang menghasilkan sebuah proses kultural produksi, dan space awal

\section{Redefenisi Playground melalui Penelitian Adventure Playground ${ }^{1}$}

Perencanaan Adventure Playground pertama yang dibuat pada Emdrup dekat dengan Copenhagen, Denmark, 1943. Th Sorensen, Arsitek yang juga telah merancang banyak playground sebelumnya menemukan bahwa anak-anak sangat suka bermain dengan materialmaterial bekas yang tersisa dari site konstruksi-konstruksi daripada playground-playground yang sudah terancang dengan baik (Frost \& Klein, 1979).

Pengamatan ini menjadi titik mula perancangan Adventure Playground pertama, yang seringkali disebut dengan Junk Playground, yang menjadi sukses besar bahkan hingga saat ini. Rekor keselamatan dari playground ini sangat baik, selain lecet, tergores, memar hanya sedikit terjadi cedera-cedera kecil (Frost \& Klein, 1979). Menurut Vance (1982) rekor keamanan untuk playground sejenis dalam waktu 10 tahun belakangan telah menunjukan bahwa playground semacam ini dapat dinyatakan aman. Sumber yang sama juga menyatakan bahwa jumlah ketertarikan anak untuk bermain juga jauh lebih tinggi daripada playground konvensional. Rudolph (1974) menyatakan bahwa ketika tantangan permainan diperkenalkan pada anakanak mereka tidak memiliki kecenderungan terhadap niatan melakukan kegiatan yang destruktif, nekat ataupun berbahaya.

\footnotetext{
${ }^{1}$ Talarowski, M. "London Study of Playgrounds: Preliminary Report", (Philadelphia: STUDIO LUDO, 2016) ; hlm. 26
} 
Melalui penelitian London Study of Playgrounds Studio Ludo menyimpulkan bahwa; ${ }^{2}$

\section{a. Kids know how to play}

Playground tidak perlu menentukan bagaimana cara bermain, dengan struktur sederhana yang memberikan ruang untuk memanjat, merosot, dan berulang. Elemen yang terbuka dan tanpa arahan, seperti jaring, alat panjat, logs, elemen yang longgar, memberikan fleksibilitas ruang kegiatan untuk bermain.

\section{b. Kids are attracted to new experiences}

Kita belajar untuk mencoba hal baru dan mencari hal yang menyenangkan yang dapat meningkatkan kemampuan kita untuk menyelesaikan sebuah tantangan dan lingkungan. Playground terbaik terlihat berbahaya namun sangat aman, memberikan cara tak terbatas untuk bermain berlandaskan dengan skill level, kekuatan, dan keberanian

\section{c. The only rule should be to have fun}

Segala sesuatu yang ada di playground harus dapat digunakan untuk bermain, karena anakanak tidak melihat perbedaan antara struktur dan genangan air. Tanaman, pohon, batu, bidang, semua dapat digunakan, tanpa ada tanda yang menyatakan "do not!"

d. Kids love to hide

Anak-anak suka membangun benteng atau sarang, mereka menyukai tempat yang kecil dan nyaman, mereka menyukai sensasi seperti menjadi tidak terlihat bahkan walaupun kita dapat melihat mereka. Playground perlu menyediakan ruang bagi anak-anak untuk berada pada dunia private mereka, sementara masih berada didalam batas ruang bermain.

\section{e. Caffeine and a bench}

Hampir semua playground yang kita kunjungi di London memiliki café dan banyak tempat duduk yang memudahkan pengamatan ke dalam playground. Hal ini menjadi ruang bagi orangtua untuk duduk dan berbincang, mengamati anak mereka, namun tetap memberikan jarak bagi anak tanpa mengganggu ataupun membantu anak untuk bermain.

\section{ANALISIS}

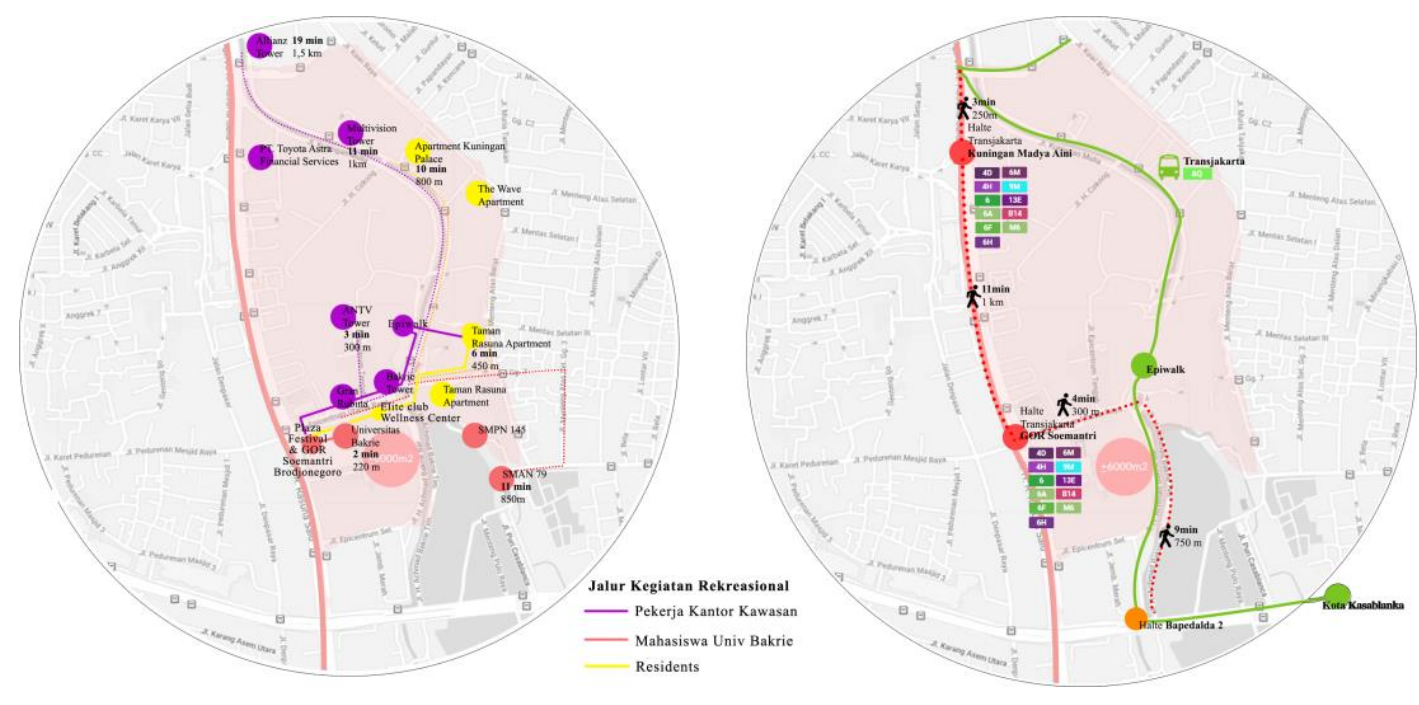

Gambar 1. Pemetaan Sifat Kegiatan dan Transportasi Umum Sumber: Penulis, 2019

2 ibid; hlm. 119 


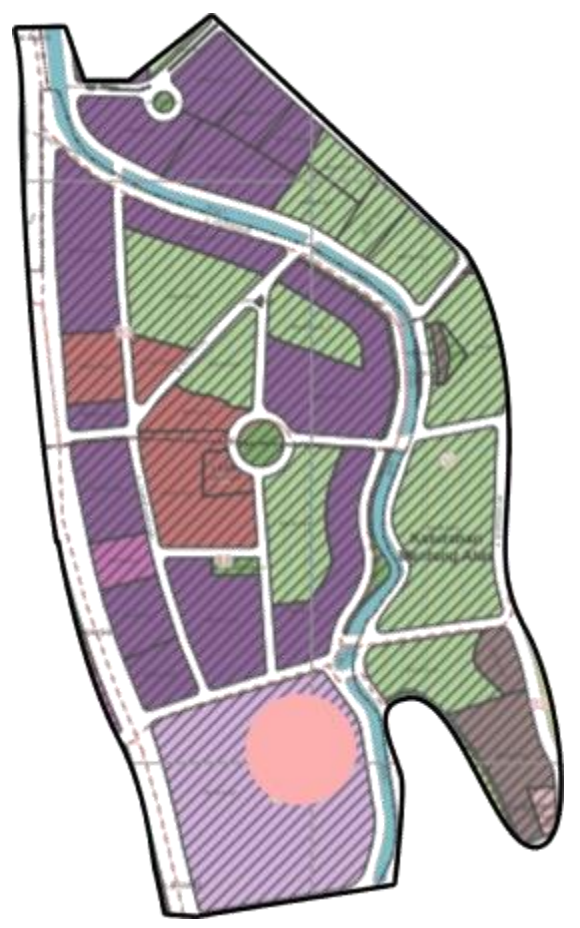

Gambar 2. Lokasi Site pada Kawasan Sumber: Penulis, 2019

\section{Metode Penelitian}

Dalam proses penelitian metode yang digunakan adalah metode observasi lapangan untuk menganalisa SWOT kawasan, pusat kegiatan, sifat kegiatan, transportasi umum, karakter lingkungan, selain itu pendataan juga dilakukan melalui metode wawancara mendalam (untuk mengetahui rencana kawasan), serta kuisioner (jumlah 200 responden)(lih. gambar 4) untuk memetakan kebutuhan masyarakat kawasan. Berikut disertakan hasil kuisioner sebagai bahan untuk menentukan fungsi bangunan terancang.
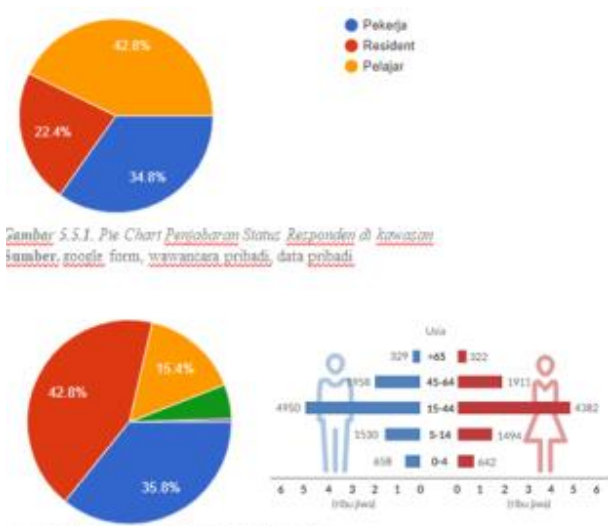

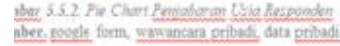

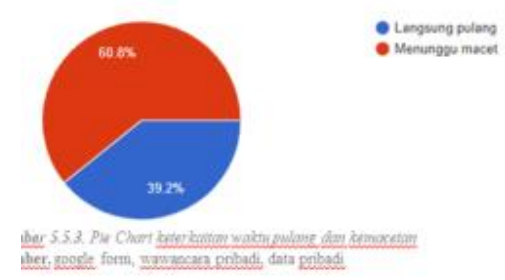

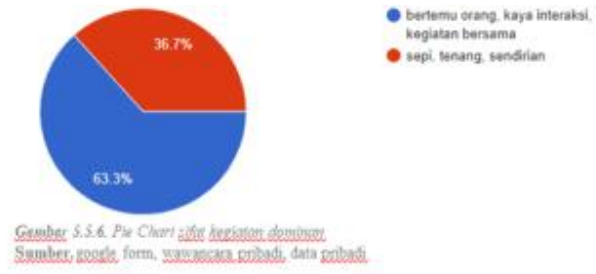
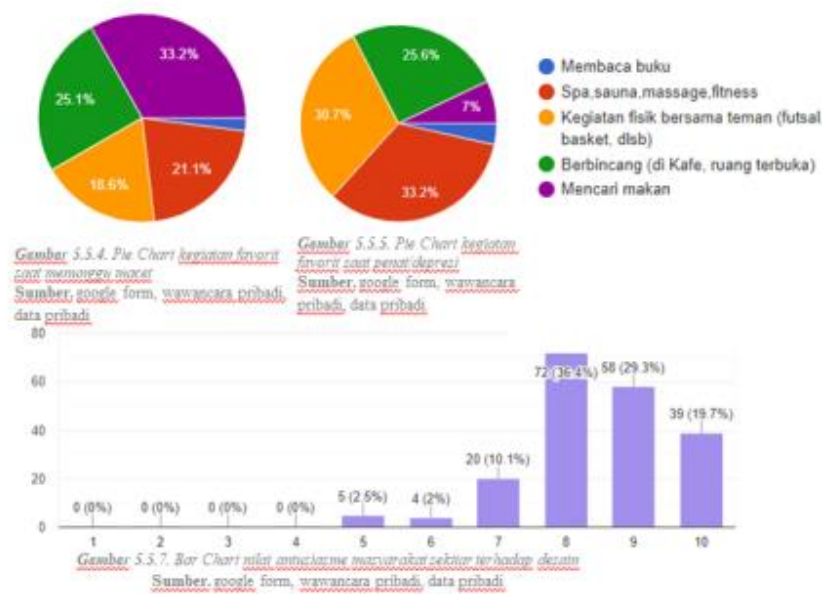

Gambar 3. Data-data hasil Kuisioner dan Wawancara

Sumber: Penulis, 2019 
Pusat Kegiatan terjadi di area utara kawasan Epicentrum, intensitas kegiatan tertinggi terjadi di sekitar Bakrie Tower Plaza Festival dan Stadion Soemantri Brodjonegoro, selain itu di sekitaran Plaza Festival terdapat area Third Place Eksisting yang sifatnya lebih komersil. Terdapat food street dan beberapa ruang olahraga untuk disewakan. Melalui wawancara dengan Head Urban Planner dari kawasan tersebut Bapak Ferri Melsont diketahui bahwa kebetulan akan dilakukan perancangan kembali area tersebut, karena adanya penyesuaian terhadap rencana pembuatan tower-tower residential di sepanjang jalan H. Rasuna Said, serta adanya relokasi Stadion Soemantri Brodjonegoro ke tepian kota, karena peraturan pemerintah baru yang melarang keberadaan stadion di pusat kota.

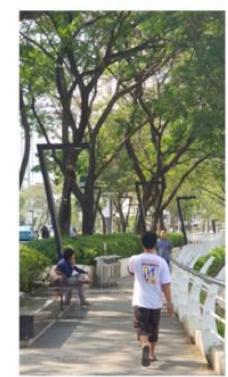

\section{Suasana Kawasan}
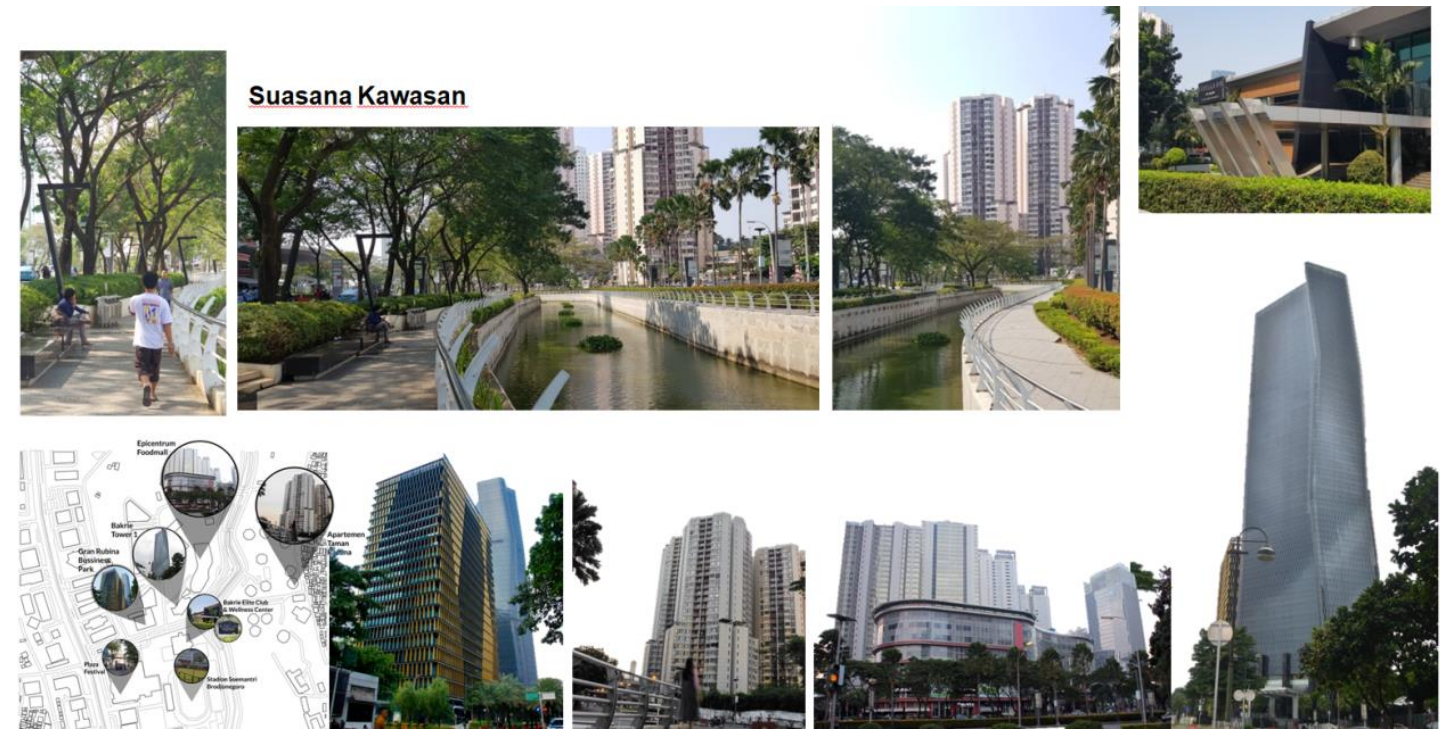

Gambar 4. Foto-foto suasana kawasan Epicentrum Sumber: Penulis, 2019

Area eksisting soemantri brodjonegoro dan sekitarnya akan dialihfungsikan menjadi ruang hijau publik sebagai fasilitas kawasan, dengan sebagian besar KDB dan KLB akan digunakan untuk tower-tower residential. Ruang bekas stadion tersebut dimanfaatkan oleh perancang sebagai tapak perancangan dengan memperhatikan peraturan,perencanaan dan fungsi-fungsi masterplan pengembang namun dengan penyesuaian program-program publik yang diperuntukkan sebagai ruang publik non-komersil bagi kawasan.(lih. gambar 6)
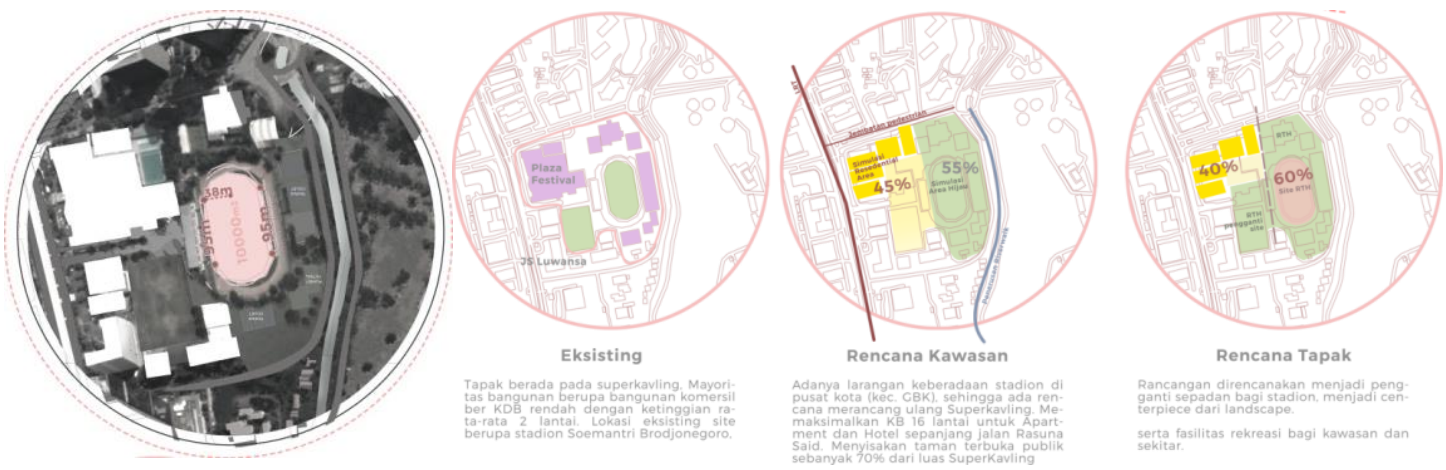

Gambar 5. Simulasi Pengelolaan Superkavling Sumber: Penulis, 2019 

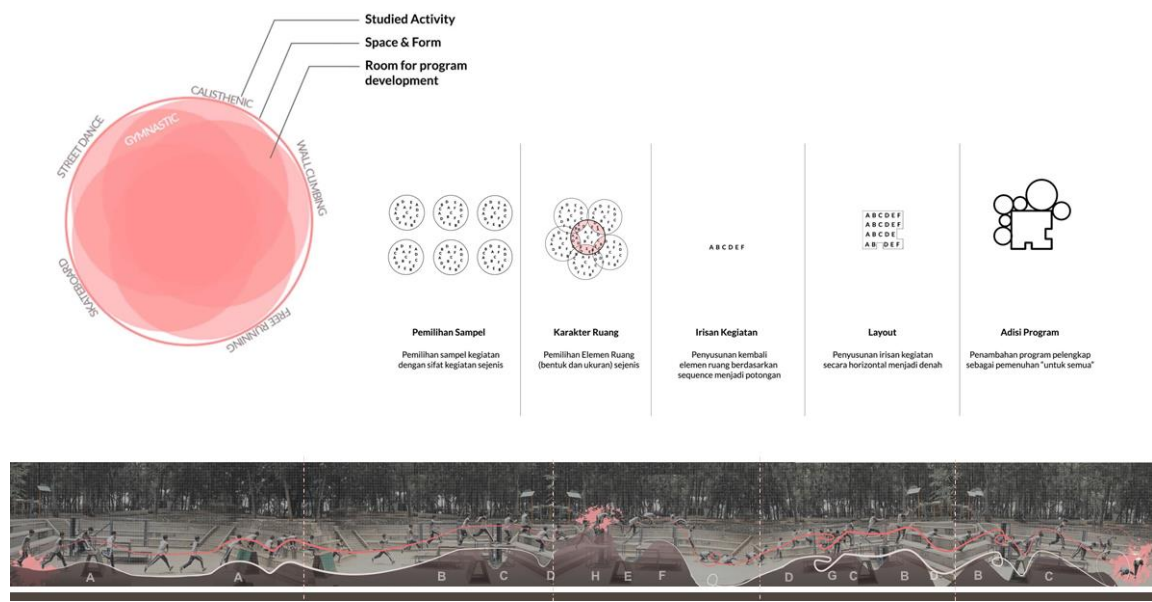

Gambar 6. Metode Elemen Ruang

Sumber: Penulis, 2019

\section{Metode Perancangan}

Sebelum memulai proses perancangan dilakukan pemilihan sampel kegiatan sejenis yang akan sesuai dengan kegiatan-kegiatan perkotaan yang sifatnya lebih informal, sederhana, dan intuitif seperti calisthenic, free running, skateboard, wall climbing dan lain sebagainya. Kegiatan-kegiatan ini kemudian dikaji dan dicari kesamaan dalam bentukan kebutuhan ruangnya, melalui pencarian kesamaan tersebut diketahui kegiatan yang paling merepresentasikan sifat keruangan yang akan dirancang. (lih. gambar 7)

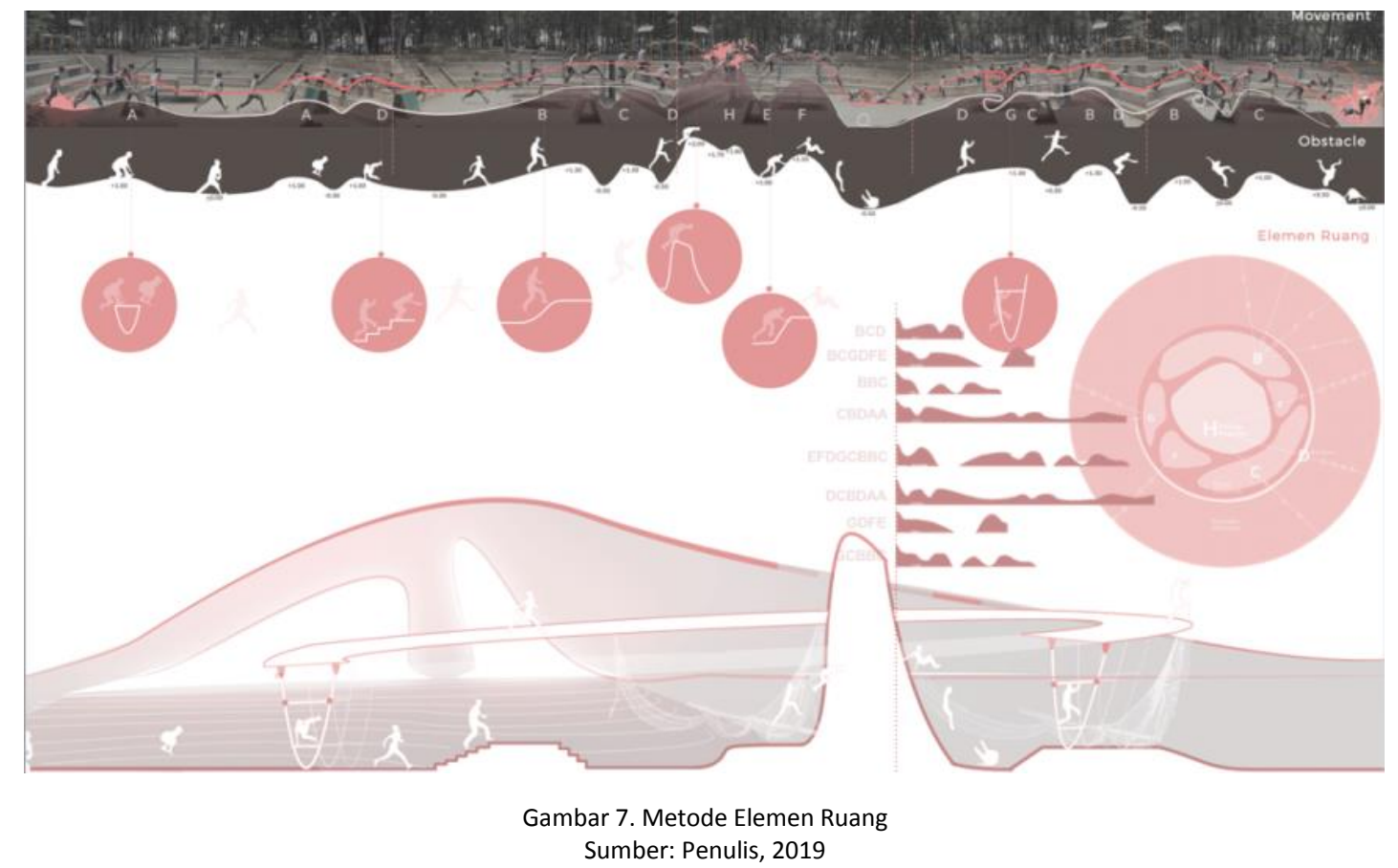

Melalui studi kegiatan tersebut dibuatlah sebuah kompilasi foto kegiatan, untuk membentuk irisan kegiatan, pencarian elemen ruang dominan serta pembentukan denah kasar. Ketiga elemen ini kemudian digunakan untuk menggambarkan sebuah potongan ide rancangan. Elemen-elemen ruang dominan kemudian ditonjolkan keluar dari selimut bangunan untuk memberikan gambaran kegiatan-kegiatan yang terjadi didalam selimut, memberikan gambaran playfullness dari rancangan.(lih. gambar 8). 

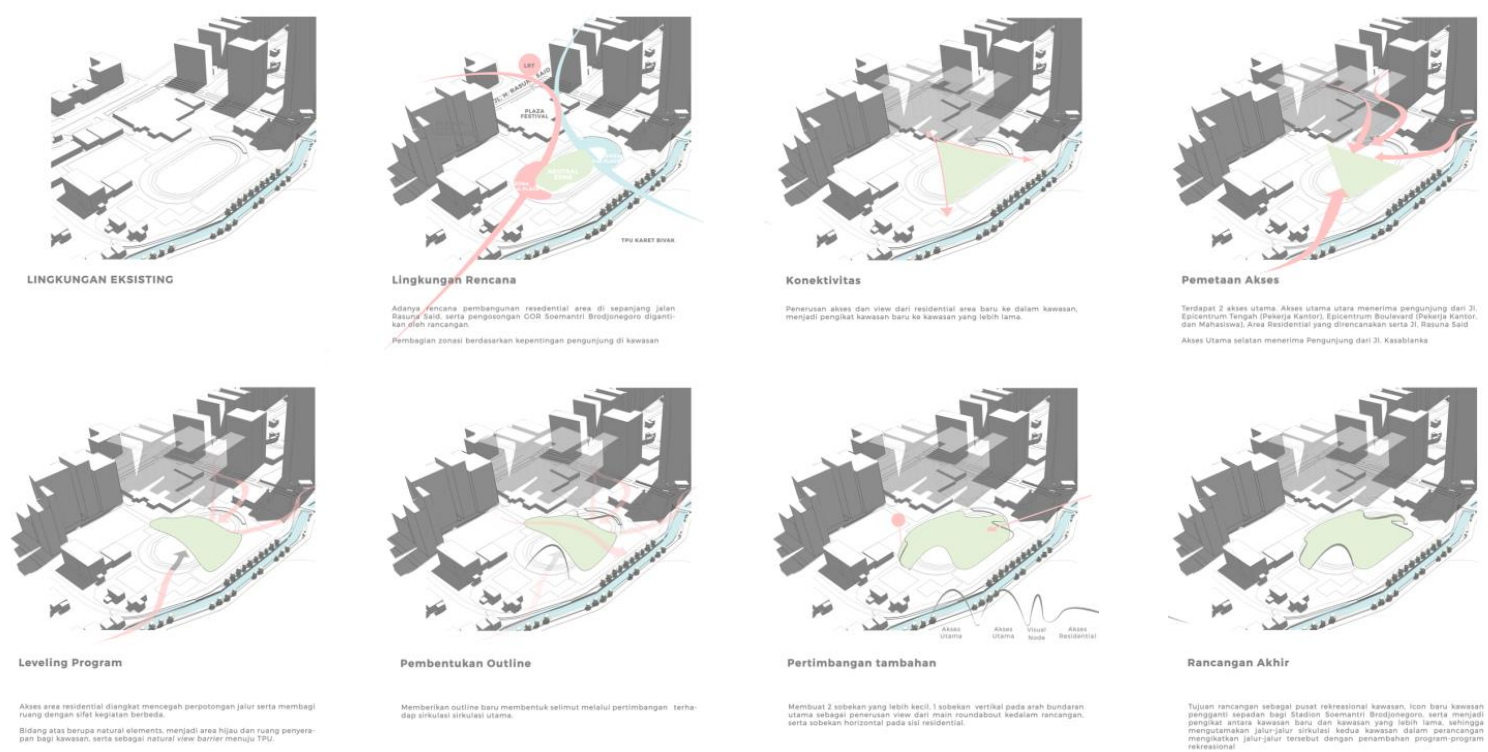

Gambar 8. Proses Perancangan Selimut bangunan dan Entrance Sumber: Penulis, 2019

Urban Playscape atau Ruang Bermain Kota Kawasan Epicentrum ,Setiabudi, Jakarta Selatan terdiri dari 2 zona besar yaitu regulated zone dan non-regulated zone dengan pembagian $40 \%$ untuk regulated zone dan 60 persen untuk non-regulated zone. Regulated Zone terdiri atas Fungsi-fungsi yang sifatnya therapy seperti : Spa, Sauna dan Recreational bath area, sedangkan area Non-regulated zone memiliki fungsi-fungsi utama sebagai berikut : Obstacle Park, Skate Park, Climbing Tower, Column Park dengan program-program pelengkap lainnya seperti spider web, multipurpose stage, serta green community plaza. Rancangan dengan luasan total $15.000 \mathrm{sqm}$ ini merupakan bangunan sunken dengan ketinggian 3 lantai yang semua areanya langsung terhubung dengan udara terbuka melalui sobekan-sobekan pada selimut bangunan. Area sunken diutamakan untuk kegiatan-kegiatan pekerja kawasan dan pelajar untuk melakukan aktivitas yang sifatnya lebih aktif (suasana kegiatan pad gambar 10) sedangkan selimut bangunan diutamakan bagi keluarga-keluarga residents yang sifat kegiatannya lebih pasif. (suasana kegiatan pada gambar 11)
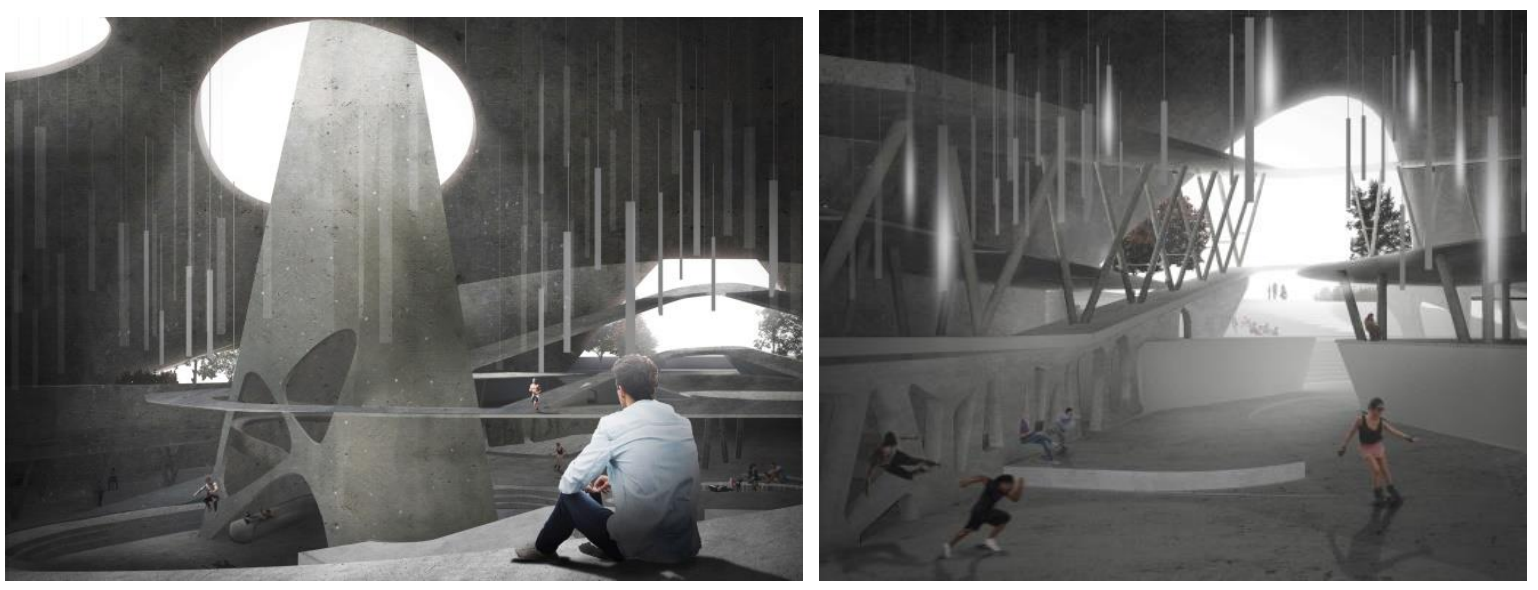

Gambar 9. Gambaran Interior Urban Playscape Sumber: Penulis, 2019

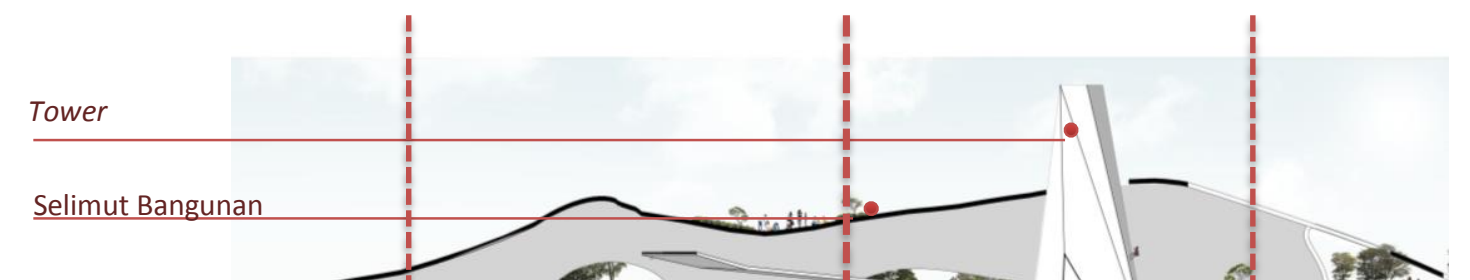


Pada perancangan sunken area elemen alam juga diikutsertakan sebagai elemen bangunan serta bagian dari permainan. Pada masa lalu bermain di luar merupakan bagian dari keseharian kita, namun anak-anak kini semakin kesulitan untuk merasakan pengalaman yang sama. Bermain di luar menjadi pengalaman yang langka. Padahal elemen-elemen alam ini yang memberikan emosi, atmosfer dan "kehidupan" tambahan kedalam permainan tersebut. Perancang membawa elemen alam ini kedalam rancangan, dengan kontrol-kontrol tertentu, untuk menghadirkan kembali hal penting yang hilang dari permainan. Rancangan yang sederhana namun memanfaatkan elemen alam serta kekayaan program sebagai titik kompleksitas rancangan.
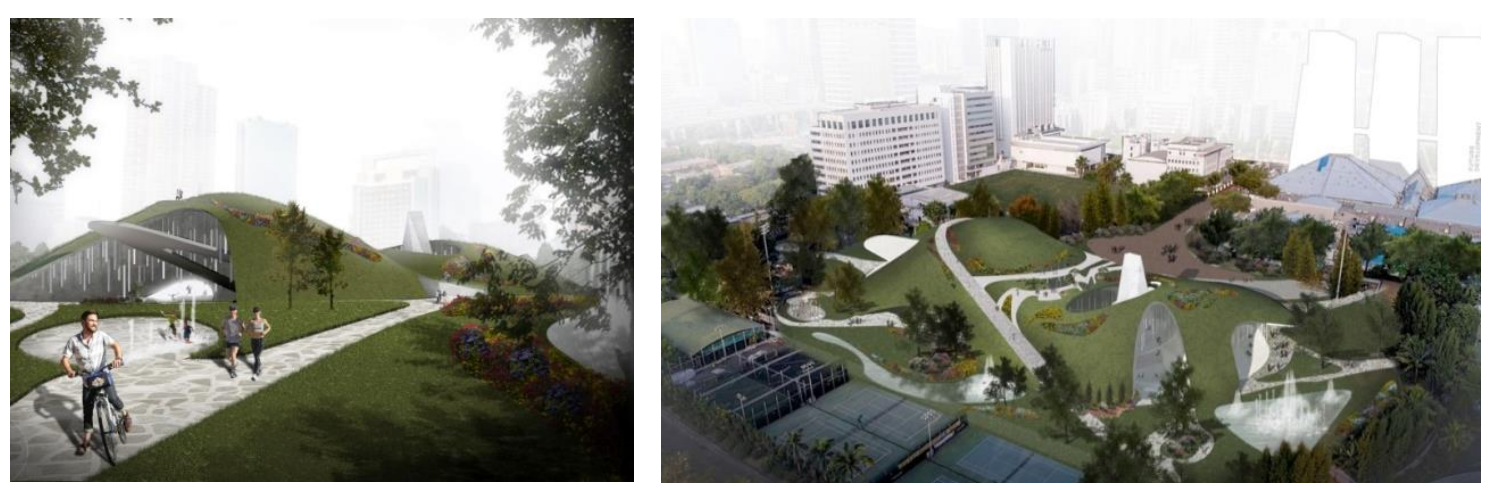

Gambar 11. Gambaran suasana eksterior Urban Playscape Sumber: Penulis, 2019

Dalam upaya merancang sebuah bangunan yang berkelanjutan rancangan dibuat dengan material yang polos, dalam upaya menekan biaya untuk maintenance, pengolahan kembali air hujan serta adanya funding silang dari program-program regulated ke program non-regulated.

Perancangan Selimut bangunan diperuntukkan sebagai ruang terbuka hijau bersama bagi keluarga, sebagai ruang untuk piknik dan menghabiskan akhir minggu bagi keluarga. Selimut ini dimanfaatkan sebagai buffer visual dan kebisingan dari sunken area menuju tower-tower residential. Sehingga semua aktivitas dapat co-exist tanpa saling mengganggu.

Dalam perancangan ruang dalam, perancang mempertimbangkan jarak personal bubble antar individu dengan kegiatan tertentu, serta penggunaan perabot dalam berkegiatan. Kedua hal ini mempengaruhi pola pengaturan program pada rancangan, Penyediaan ruang yang aktif pada center of the Building, serta ruang-ruang yang lebih pasif disekitarnya. Pola penyusunan radial terhadap ruang kegiatan yang lebih aktif.

Ruang kegiatan pasif ditujukan bagi orang yang memiliki preferensi untuk bersantai pada ruang publik, ruang ini memiliki jarak antar kegiatan lebih jauh, serta jarak personal bubble yang lebih besar. (lih. gambar 12) 


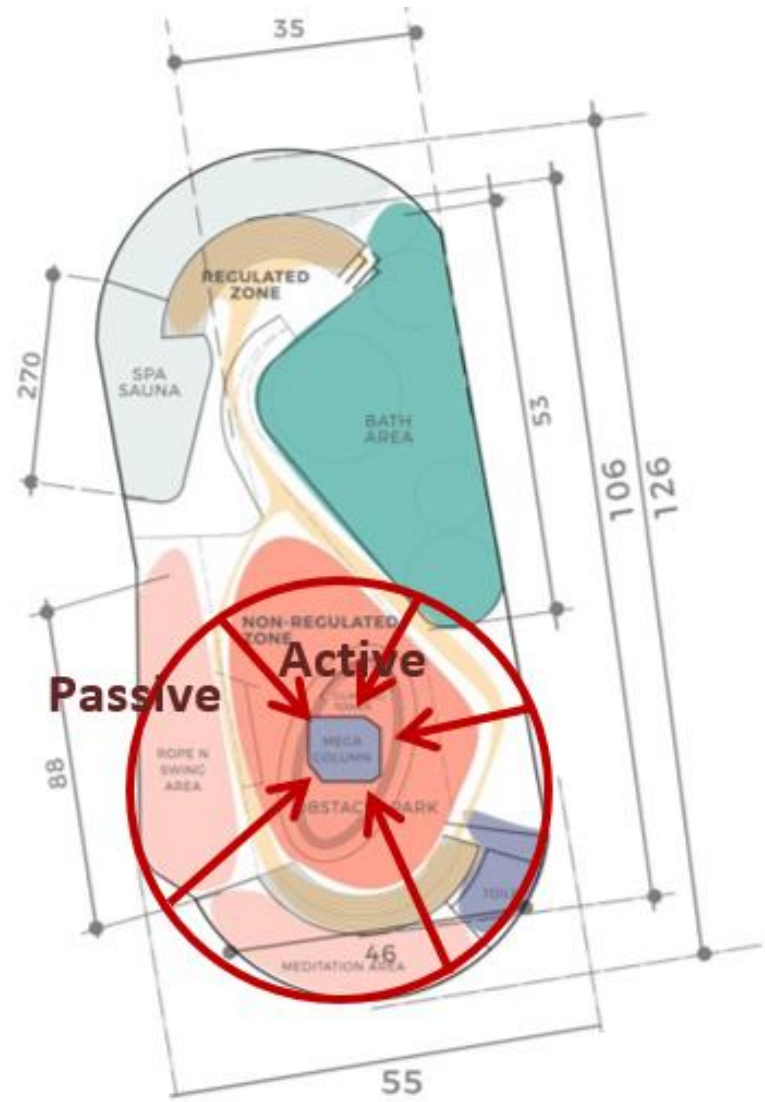

Gambar 12. Denah Underground 2 Sumber: Olahan Penulis, 2019

Ruang kegiatan aktif ditujukan bagi orang yang memiliki preferensi untuk kegiatan intensitas tinggi, berinteraksi dengan orang lain, sehingga memiliki jarak antar kegiatan yang lebih rapat dan personal bubble yang lebih kecil. (lih. gambar 12)

Sedangkan dalam pertimbangan mengenai kegiatan "berperabot" dan yang tidak, penyusunan ruang lebih diatur melalui sequence kegiatan. Kegiatan perabot (skate-park) diletakkan pada Underground 1 dalam upaya "membersihkan" area tanpa perabot (obstacle park)pada Underground 2 dari kegiatan-kegiatan berkecepatan lebih tinggi yang dapat menyebabkan kecelakaan bagi user tanpa perabot. Kemudian lokasi zona secara vertikal dipisahkan dengan pertimbangan potential user dari tiap program. (lih. gambar 13)

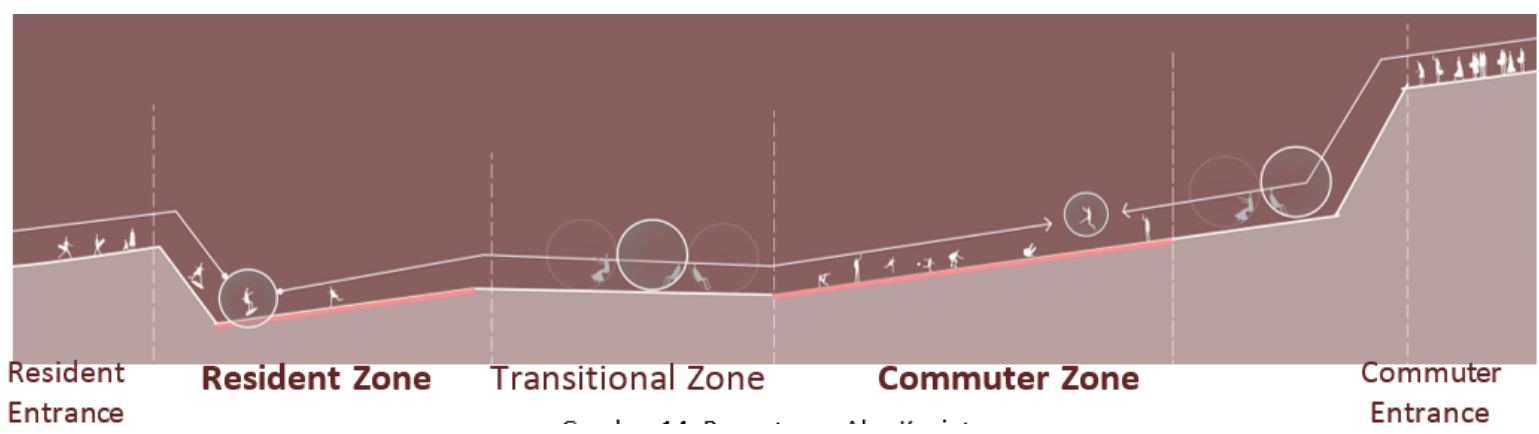

Gambar 13. Pengaturan Alur Kegiatan Sumber: Olahan Penulis, 2019 


\section{KESIMPULAN DAN SARAN}

Pengelola Kawasan Epicentrum dinilai perlu lebih memperhatikan kebutuhan masyarakat kawasan akan ruang-ruang rekreasional publik di kawasan. Pengembangan kawasan yang profit-oriented oleh pengelola kawasan, menghasilkan kawasan yang indah tapi tidak hidup. Usulan Ruang Bermain Kota Kawasan Epicentrum ini ditujukan sebagai suatu platform interaksi dan bermain masyarakat kota yang inklusif dan berkelanjutan yang bertujuan sebagai jembatan penghubung antara kebutuhan masyarakat kawasan dengan kepentingan pengembang, yang juga dapat di implementasikan ke tempat lain dengan penyesuaian terhadap user, budaya setempat, serta sifat lingkungannya.

\section{REFERENSI}

Anggraini, A.P. (2018,22 Januari) Rutinitas Kerja, Penyebab Stres yang Paling Umum. Dikutip 15 Agustus 2019 dari Kompas.com: https://lifestyle.kompas.com/read/2018/01/22/182932320/rutinitas-keria-penyebabstres-yang-paling-umum

Chase, R. (2015.) Peer Inc, BBS Public Affairs

Fu Tuan, Y. (1977). Space and Place: Humanistic Perspective, Minneapolis : University of Minnesota Press

Oldenberg,R. (1999.) The Great Good Place, New York : Marlowe\& co,

Misha (2018,25 Mei) How to Break Routine and Get More "Aha" Moments in Life. Dikutip 3 Agustus 2019 dari Medium.com: https://medium.com/@mishablog/how-to-breakroutine-and-get-more-aha-moments-in-life-5909874a095e

Susan, C. (1985). Adventure Playgrounds vs Traditional Playgrounds, Florida: University of North Florida

Talarowski, M. (2016). London Study of Playgrounds: Preliminary Report, Philadelphian: STUDIO LUDO 
